\title{
Correction to: A Proposed Treatment Approach to Treat Lethal Mutating Cancers
}

Kevin Roe ' (D)

Published online: 16 March 2020

(C) Springer Science+Business Media, LLC, part of Springer Nature 2020

\section{Correction to: Pharm Res}

https://doi.org/ | 0.1007/s I | 095-020-2776-3

On the first page, third paragraph of the introduction, the second sentence should have a typographical correction to state -.

For example, cancer epithelial cells will activate the NKG2D cell surface receptor on natural killer $(\mathrm{NK})$ cells of the innate immune system, and activate the $\gamma: \delta \mathrm{T}$ cells and cytotoxic CD8 $\mathrm{T}$ cells of the adaptive immune system (4-6).

Publisher's Note Springer Nature remains neutral with regard to juris-dictional claims in published maps and institutional affiliations. 